\title{
DAMPAK DAN STRATEGI KEBIJAKAN PENGEMBANGAN PEMBIAYAAN DAN INKLUSIFITAS KEUANGAN DALAM PENINGKATAN PEMBIAYAAN BANK SYARIAH DI INDONESIA
}

\author{
Binti Nur Asiyah \\ IAIN Tulungagung \\ binti_nur@yahoo.co.id; binti.advan@gmail.com
}

\begin{abstract}
This paper is motivated by the policy of the Financial Services Authority, in which Shariah Banking is able to compete and perform the intermediation function equally and felt by the people of Indonesia. The policy of the Financial Services Authority has a synergy between sharia banking and the Community in the form of easily accessible financing. This paper aims to determine the impact and strategy of development policy of Financing and financial inclusiveness in increasing the financing of Bank Syariah in Indonesia. The method used is qualitative approach, descriptive type. The result of this paper is the policy of development of financing and financial inclusions have a significant impact for the improvement of financing. The strategies for the policy to produce maximum financing; first the need for support from the government as regulatory publishers, universities, state enterprises to support the financing climate; secondly, the shift of regulatory thinking from the achievement of the quantity of funds alone, but also must be based on the number of people who can be served. Third Improvement of Sharia Banking Human Resources with the training policy, providing sufficient incentives and minimum standards for recruitment of sharia banking managers. Thirdly, sharia banking always considers Third Party Funds Management, Fourth; consider the profit-sharing rate used in the financing contract. Fifth, Sharia Banks have the opportunity to cooperate (chanelling) with Non-Governmental Groups that have been free from poverty, and maximize financing for the allocation of Micro Small and Medium Enterprises.
\end{abstract}

Keywords: Financing, Working Capital, Financing development policy 


\section{A. Pendahuluan}

Fakta yang menunjukkan bahwa (www. keuangan. contan. co. id) Otoritas Jasa Keuangan Syariah tahun 2015 telah mengeluarkan kebijakan dalam outlook Perbankan Syariah tahun 2015; Pertama, pengembangan produk, yang utamanya terkait aktivitas usaha dan kelembagaan yang lebih terintegrasi dan sinergis. Kedua, pengembangan pembiayaan dan layanan yang mendukung sektor ekonomi prioritas, inklusi finansial dan pembiayaan produktif. Kebijakan ketiga, penguatan kolaborasi antar otoritas dalam mendukung pengembangan perbankan syariah. Sementara, keempat adalah penguatan harmonisasi pengaturan dan kebijakan sesama perbankan maupun antar jasa keuangan yang tetap memperhatikan karakteristik syariah. Dan kelima, adalah promosi dan edukasi perbankan syariah yang lebih terstruktur, terintegrasi dan sinergis.

Masalah ini penting untuk dipecahkan, mengingat pertumbuhan Kebijakan Otoritas Jasa Keuangan menunjukkan adanya nilai positif bagi perkembangan pengelolaan aset produktif Perbankan Syariah.

\section{Tabel. 1}

Perkembangan Aset Produktif (Bank dan non bank) Bank Umum Syariah (satuan milyar rupiah)

\begin{tabular}{cccc}
\hline Keterangan & Tahun 2014 & 2015 & 2016 \\
\hline Aset produktif & 262,723 & 285,200 & 345,443 \\
$\%$ peningkatan & & $8,55 \%$ & $21,12 \%$ \\
\hline
\end{tabular}

Sumber: diolah dari Statistik Perbankan Syariah Desember 2016

Data di atas menunjukkan adanya kenaikan dalam pengelolaan asset produktif. Diperlukan upaya-upaya agar aset produktif kian meningkat, membutuhkan inovasi-inovasi produk yang dibutuhkan oleh masyarakat. Secara umum seperti yang dilakukan oleh Bank Syariah mandiri melalui produk warung mikro, dan Bank Muamalat Indoenisia dengna produk Mu'amalat mikro. Namun kondisi tersebut nampaknya belum diimbangi dengan adanya mitigasi risiko penyaluran pembiayaan kepada masyarakat. 
Tabel. 2

Perkembangan Financing to Deposit Ratio Bank Umum Syariah (satuan milyar dan persen)

\begin{tabular}{cccc}
\hline Keterangan & Tahun 2014 & 2015 & 2016 \\
\hline FDR & $86.7 \%$ & $88 \%$ & $86 \%$ \\
Pembiayaan (selain bank) & 147944.4678 & 153968 & 177482.0804 \\
Dana Pihak Ketiga & 170722.9292 & 174895 & 206406.6839 \\
\hline
\end{tabular}

Sumber: diolah dari Statistik Perbankan Syariah Desember 2016

Fakta-fakta tersebut menjadikan penting untuk dikaji bahwa seiring keberhasilan inklusifitas keuangan Bank Umum Syariah sehingga mampu menarik simpati masyarakat agar menaruh dana yang dimiliki ke dalam Bank Syariah belum memberikan keseimbangan pada pembiayaan yang bisa diterima oleh nasabah financing. Artinya bentuk pengembangan pembiayaan perlu dilihat lebih jauh serta bentuk inklusifitas keuangan masih perlu dipertegas, baik dalam fungsi intermediasi funding maupun financing.

Hal tersebut juga senada dengan hasil praktik mahasiswa bahwa dari sekitar 1550 calon nasabah salah satu Bank Umum Syariah, bahwa produk pembiayaan yang ditawarkan bank umum syariah belum sepenuhnya merepresentasikan kebutuhan masyarakat. Faktor utama yang dikeluhkan masyarakat adalah tingginya target pembiayaan yang akan diberikan. Salah satu Bank Umum Syariah menawarkan produk pembiayaan minimal 25 juta dengan margin 1,6\%. Hal ini menurut calon nasabah terlalu tinggi jika dibandingkan dengan Bank Konvensional. Bank Umum Syariah membutuhkan kebijakan-kebijakan sehingga apa yang menjadi keputusan komite asset dan liabilitas, disambut baik oleh calon nasabah sehingga akan memberikan keputusan untuk memilih pembiayaan di bank Umum Syariah. Selain itu bidang-bidang tertentu yang memiliki risiko tinggi seperti pertanian, peternakan tidak menjadi sasaran pembiayaan. Hal ini bertentangan dengan prinsip inklusi keuangan, bahwa diharapkan Pembiayaan tidak saja secara kuantitas semata pembiayaan tersalurkan, tetapi bagaimana pembiayaan mampu di akses oleh seluruh masyarakat.

Kajian tentang inklusifitas keuangan telah banyak dikaji. Sebagaimana dalam paper Wati (2016, h.1-8) yang bertujuan untuk menganalisis keuangan inklusif Bank Umum Syariah dalam 
mendukung UMKM, dengan pendekatan kuantitatif dan jenis deskriptif menghasilkan bahwa preferensi bank umum syariah atas akses UMKM tidak terkait dengan ukuran bank. Meskipun jaringan kantor Bank Umum Syariah mengalami kenaikan, namun jangkauan fisik belum merata. UMKM masih memeiliki keterjangkauan harga yang rendah, sebaliknya dengan BPRS. Selain itu ketika keterjangkauan harga rendah, maka Non Performing Financing (NPF) UMKM akan tinggi. Perbedaan dengan penelitian yang sedang dikaji adalah inklusifitas dalam penelitian ini diarahkan terhadap peningkatan pembiayaan. Hal ini berharap bisa mengejar ketertinggalan dengan Bank Umum Konvensional dalam mengejar target pasar.

Kondisi di atas menjadi penting untuk membuktikan bahwa kebijakan Otoritas Jasa Keuangan dalam pengembangan pembiayaan dan inklusifitas keuangan dapat memberikan dampak terhadap peningkatan pembiayaan pada perbankan syariah di Indonesia. Paper ini diharapkan mampu memberikan solusi atas rendahnya market share bank syariah dengan memberikan solusi berupa pengembangan pembiayaan dan inklusifitas keuangan dapat memberikan dampak terhadap peningkatan pembiayaan non bank di Bank Umum Syariah di Indonesia. Upaya memaksimalkan market share tentu banyak hal yang perlu dilakukan. Otoritas Jasa Keuangan mendorong unit usaha syariah untuk berubah kelembagaan menjadi Bank Umum Syariah. Dengan demikian Bank Syariah memiliki kebijakan untuk menentukan untuk meningkatkan funding maupun financing. Berbeda jika masih berada pada Unit Usaha Syariah, maka kebijakan berada pada Bank Induk yaitu Bank Konvensional.

Kajian tentang pengembangan perbankan syariah sebagaimana kajian ULUM (2016) yang bertujuan untuk mengelaborasi pentingnya Inovasi Produk Perbankan Syariah di Indonesia menghasikan bahwa seiring dengan perkembangan perbankan syariah, maka kebutuhan pengembangan produk juga semakin bertambah. Hal ini semata-mata untuk memenuhi kebutuhan pasar perbankan syariah yang terus meningkat. Secara garis besar, pengembangan produk perbankan syariah selain harus mengikuti kebutuhan pasar, juga harus didasarkan pada kepatuhan terhadap syariah, oleh karena itu 
harus ada dasar fatwa dari Dewan Syariah Nasional. Dalam aplikasi perjalanan perbankan syariah hingga saat ini, terdapat beberapa fatwa yang terkendala aplikasinya dalam produk, ada beberapa fatwa penghimpunan dana dan penyaluran dana serta fatwa yang menyangkut treasury yang mendesak untuk segera diterbitkan. Maka inovasi produk yang mampu memenuhi kebutuhan pasar dan sekaligus taat syariah mutlak diperlukan untuk meningkatkan daya saing perbankan syariah baik secara domestik, regional maupun kompetisi global di era pasar bebas dengan antisipasi berbagai peluang dan tantangannya.

\section{B. Kajian Pustaka}

\section{Inovasi dan Pengembangan Pembiayaan}

Inovasi Pembiayaan menjadi suatu kebutuhan bagi masyarakat. Realitas menunjukkan bahwa masyarakat tahunya adalah memerlukan uang untuk usaha, membeli rumah, pendidikan anak, kesehatan dan lain sebagainya. Namun demikian kesadaran masyarakat untuk berhubungan dengan perbankan syariah tentu masih harus diperdalam. Hal tersebut sebagai upaya untuk terus meningkatkan peran Perbankan Syariah dalam menciptakan perekonomian Indonesia yang stabil dan terus meningkat. Upaya pengembangan Perbankan syariah dapat diukur melalui kinerja perusahaan Perbankan.

Venkatraman dan Ramanujam (1986: 801-814) menyatakan bahwa kinerja perusahaan terdiri dari kinerja keuangan, kinerja bisnis, dan kinerja keorganisasian. Kinerja keuangan diukur dari penerimaan atas aset (return on asset), penerimaan atas penjualan (return on sales), dan return on equity. Indikator kinerja keuangan Perbankan Syariah dapat dilihat dari Keuntungan yang diperoleh tiap bulannya, rasio penyaluran dana dibandingkan dengan dana funding yang berhasil dihimpun.

\section{Inklusifitas Perbankan Syariah}

Teori inklusifitas sebagaimana dalam Rhyne (2009; h.99) bahwa "inclusive finance is requires regulators to pay attention to institutions that serve many people even though monetary amount may be insignificant". Dalam konsep ini agar setiap masyarakat bisa 
mendapatkan pelayanan dari Perbankan Syariah maka perlu bagi setiap regulator yang berperan senantiasa memperhatikan perbankan syariah. Rhyne menjelaskan bahwa "Regulators usually think the other way around, on the theory that the large players determine the heal th of the financial system as a whole, measured by volume of funds, not people services". Dalam rangka mewujudkan inklusifitas keuangan pada perbankan syariah, maka pandangan para regulators harus bergeser dari kuantitas dana semata, tetapi juga harus didasarkan pada jumlah orang yang bisa dilayani dari dana tersebut.

Bank Indonesia pada dasarnya jauh hari sudah mengatur terkait Batas Maksimum Pemberian Kredit (BMPK). Pertama Batas Maksimum Pemberian Kredit (BMPK) no 7/03/PBI/2007 tentang Batas Maksimum Pemberian Kredit Bank UMUM, bahwa seluruh Portofolio penyediaan dana kepada pihak terkait bank ditetapkan paling tinggi sebesar 10 persen dari modal bank. Sedangkan penyediaan dana kepada satu peminjam bukan merupakan pihak terkait bank ditetapkan paling tinggi sebesar 20 persen dari modal bank, penyediaan dana kepada satu kelompok peminjam bukan merupakan pihak terkait bank ditetapkan paling tinggi sebesar 25 persen dari modal bank.

Pihak tidak terkait yang dimaksud meliputi; perseorangan atau perusahaan/badan yang merupakan pengendali bank; perusahaan/ badan bertindak sebagai pengendali bank; perseorangan/ perusahaan/badan yang bertindak sebagai pengendali perusahaan; Komisaris, direksi, dan pejabat eksekutif bank; pihak yang memiliki hubungan dengan keluarga sampai dengan derajat kedua, baik secara horisontal maupun vertikal, perusahaan/badan yang memilik ketergantungan keuangannya (financial interdependence) kepada Bank; kontrak investasi kolektif dimana bank atau pihak-pihak yang disebut memiliki $10 \%$ atau lebih saham pada manajer investasi kontrak investasi kolektif tersebut; peminjam perseorangan/ perusahaan/badan bukan bank yang memiliki jaminan kepada pihak-pihak terkait tersebut, peminjam yang diberikan jaminan oleh pihak-pihak tersebut, bank lain yang memberikan jaminan kepada pihak-pihak terkait tersebut sepanjang terdapat counterguarantee dari bank dan atau pihak-pihak sebagaimana dimaksud di atas, pengendali apabila perseorangan/perusahaan/badan secara 
langsung atau tidak langsung memiliki secara sendiri-sendiri atau bersama $10 \%$ dari saham bank atau perusahaan/badan lain.

Selain itu pihak terkait yang dimaksud memiliki hak opsi atau hak lainnya untuk memiliki saham yang apabila digunakan akan menyebabkan pihak tersebut memiliki dan atau mengendalikan secara sendiri atau bersama-sama $10 \%$ dari saham bank atau perusahaan/badan lain; melakukan kerjasama atau tindakan yang sejalan untuk mencapai tujuan bersama dalam mengendalikan bank atau perusahaan/badan lain (acting in concert) dengan atau tanpa perjanjian tertulis dengan pihak lain, sehingga secara bersama-sama memiliki dan atau mengendalikan 10 persen, atau lebih saham bank atau perusahaan/badan lain; melakukan kerjasama atau tindakan yang sejalan untuk mencapai tujuan bersama dalam mengendalikan bank atau perusahaan/badan lain (acting in concert), dengan atau tanpa perjanjian tertulis dengan pihak lain tersebut, sehingga secara bersama-sama mempunyai hak opsi atau hak lainnya untuk memiliki saham, yang apabila hak tersebut dilaksanakan menyebabkan pihak-pihak tersebut memiliki dan atau mengendalikan secara bersama-sama 10\% (sepuluh perseratus) atau lebih saham Bank atau perusahaan/badan lain;

Pihak terkait tersebut memiliki kewenangan dan atau kemampuan untuk menyetujui, mengangkat dan atau memberhentikan anggota Komisaris dan atau Direksi Bank atau perusahaan/badan lain; memiliki kemampuan untuk menentukan (controlling influence) kebijakan operasional atau kebijakan keuangan Bank atau perusahaan/badan lain; mengendalikan 1 (satu) atau lebih perusahaan lain yang secara keseluruhan memiliki dan atau mengendalikan secara bersama-sama 10\% (sepuluh perseratus) atau lebih saham Bank atau perusahaan/badan lain;

Pengendali sebagaimana dimaksud di atas adalah apabila perseorangan atau perusahaan/badan secara langsung atau tidak langsung: a. memiliki 10\% (sepuluh perseratus) atau lebih saham perusahaan/badan lain dan porsi kepemilikan tersebut merupakan porsi yang terbesar; b. memiliki secara sendiri atau bersama-sama 25\% (dua puluh lima perseratus) atau lebih saham perusahaan/ badan lain; c. memiliki hak opsi atau hak lainnya untuk memiliki saham yang apabila digunakan akan menyebabkan pihak tersebut 
memiliki dan atau mengendalikan saham perusahaan/badan lain sebagaimana dimaksud pada huruf a atau huruf b; d. melakukan kerjasama atau tindakan yang sejalan untuk mencapai tujuan bersama dalam mengendalikan perusahaan/badan lain (acting in concert), dengan atau tanpa perjanjian tertulis dengan pihak lain, sehingga secara bersama-sama memiliki dan atau mengendalikan saham perusahaan lain sebagaimana dimaksud pada huruf a atau huruf b; e. melakukan kerjasama atau tindakan yang sejalan untuk mencapai tujuan bersama dalam mengendalikan perusahaan/badan (acting in concert), dengan atau tanpa perjanjian tertulis dengan pihak lain tersebut, sehingga secara bersama-sama mempunyai hak opsi atau hak lainnya untuk memiliki saham, yang apabila hak tersebut dilaksanakan menyebabkan pihak-pihak tersebut memiliki dan atau mengendalikan secara bersama-sama saham perusahaan/ badan lain sebagaimana dimaksud; f. memiliki kewenangan dan atau kemampuan untuk menyetujui, mengangkat dan atau memberhentikan anggota Komisaris dan atau Direksi perusahaan/ badan lain; g. memiliki kemampuan untuk menentukan (controlling influence) kebijakan operasional atau kebijakan keuangan perusahaan/badan lain.

Kedua Batas Maksimum Pemberian Kredit Bank Pembiayaan Rakyat Syariah (PBI no 13/5/PBI/2011) konten isinya sebagaimana pada BMPK Bank Umum, namun terdapat penambahan bahwa Penyaluran Dana dalam bentuk Pembiayaan kepada 1 (satu) kelompok Nasabah Penerima Fasilitas yang merupakan Pihak Tidak Terkait ditetapkan paling tinggi 30\% (tiga puluh persen) dari Modal BPRS. Ketiga Batas Maksimum Pemberian Kredit Bank kepada UMKM (PBI no 14/22/PBI/2012) dimana jumlah pembiayaan kepada UMKM paling rendah adalah $20 \%$ dari total pembiayaan. Hal tersebut dilakukan secara bertahap. Tahun 2015 capaian pembiayaan kepada UMKM paling rendah 5\% dari total pembiayaan, tahun 2016 capaian pembiayaan kepada UMKM paling rendah 10\% dari total pembiayaan, tahun 2017 capaian pembiayaan kepada UMKM paling rendah 15\% dari total pembiayaan, dan tahun 2018 capaian pembiayaan kepada UMKM paling rendah $20 \%$ dari total pembiayaan. Harapanya dengan adanya regulasi tersebut, pembiayaan yang diberikan perbankan 
bisa mengena kepada UMKM. Namun demikian hal tersebut dalam kuantitas dana, tetapi seberapa besar nasabah UMKM yang terlibat, masih lepas dari jangkauan regulasi.

\section{Pembiayaan di Bank Syariah}

Pembiayaan jika dilihat dari pengertiannya sungguh luas adanya. Sebagaimana dalam bukunya Asiyah (2014) bahwa Pembiayaan dimaknai sebagai penyediaan dana atau tagihan yang dipersamakan dengan itu berupa: (a) transaksi bagi hasil dalam bentuk mudharabah dan musyarakah; (b) transaksi sewa-menyewa dalam bentuk ijarah atau sewa beli dalam bentuk ijarah muntahiyah bit tamlik; (c) transaksi jual beli dalam bentuk piutang murabahah, salam, dan istish'na, (d) transaksi pinjam meminjam dalam bentuk piutang qardh; dan (e) transaksi sewa-menyewa jasa dalam bentuk ijarah untuk transaksi multijasa; berdasarkan persetujuan atau kesepakatan antara bank syariah serta atau UUS dan pihak lain yang mewajibkan pihak yang dibiayai dan / atau diberi fasilitas dana untuk mengembalikan dana tersebut setelah jangka waktu tertentu dengan imbalan ujrah, tanpa imbalan, atau bagi hasil. Melihat definisi tersebut pembiayaan memiliki cakupan dan objek yang luas. Sehingga harapan untuk mengembangkan pembiayaan ke arah objek yang didanai mendapat respon positif dari masyarakat.

Tujuan pembiayaan menurut Asiyah (2014) adalah memberi manfaat secara makro ekonomi, dan tujuan pembiayaan untuk tingkat mikro. Secara makro dijelaskan bahwa pembiayaan bertujuan:

a. Peningkatan ekonomi umat, artinya: masyarakat yang tidak dapat akses secara ekonomi, dengan adanya pembiayaan mereka dapat melakukan akses ekonomi.

b. Tersedianya dana bagi peningkatan usaha, artinya untuk pengembangan usaha membutuhkan dana tambahan. Dana tambahan ini dapat diperoleh melalui aktivitas pembiayaan. Pihak yang surplus dana menyalurkan kepada pihak yang minus dana, sehingga dapat digulirkan.

c. Meningkatkan produktivitas, artinya adanya pembiayaan memberikan peluang bagi masyarakat agar mampu meningkatkan daya produksinya. 
d. Membuka lapangan kerja baru artinya: dengan dibukanya sector-sektor usaha melalui penambahan dana pembiayaan, maka sector usaha tersebut akan menyerap tenaga kerja.

e. Terjadinya distribusi pendapatan, artinya masyarakat usaha produktif mampu melakukan aktivitas kerja, berarti mereka akan memperoleh pendapatan dari hasil usahanya.

Adapun secara mikro menurut Asiyah (2014), pembiayaan bertujuan untuk:

a. Upaya memaksimalkan laba, artinya setiap usaha yang dibuka memiliki tujuan tertinggi, yaitu menghasilkan laba usaha. Setiap pengusaha menginginkan mampu mencapai laba maksimal. Untuk dapat menghasilkan laba maksimal maka mereka perlu dukungan dana yang cukup.

b. Upaya meminimalkan risiko, artinya: usahan yang dilakukan agar mampu menghasilkan laba maksimal, maka pengusaha harus mampu meminimalkan risiko yang mungkin timbul. Risiko kekurangan modal usaha dapat diperoleh melalui tindakan pembiayaan.

c. Pendayagunaan sumber ekonomi, artinya sumber daya ekonomi dapat dikembangkan dengan melakukan mixing antara sumber daya alam dengan sumber daya manusia serta sumber daya modal. Jika sumber daya alam dan sumber daya manusianya ada, dan sumber daya modal tidak ada, maka dipastikan diperlukan pembiayaan. Dengan demikian, pembiayaan pada dasarnya dapat meningkatkan daya guna sumber-sumber daya ekonomi.

Penyaluran kelebihan dana, artinya: dalam kehidupan masyarakat ada pihak yang kelebihan dana, sementara ada pihak yang kekurangan dana. Dalam kaitan dengan masalah dana, maka mekanisme pembiayaan dapat menjadi jembatan dalam penyeimbangan dan penyaluran kelebihan dana dari pihak yang kelebihan (surplus) kepada pihak yang kekurangan (minus) dana. Kondisi demikian memberikan kesempatan kepada masyarakat yang memiliki dana, namun tidak memiliki kemampuan usaha, maka uang yang dimiliki bisa berputar. Dana tersebut memberikan manfaat bagi orang yang memiliki keahlian untuk meningkatkan 
usahanya, menambah laba dan memberi keuntungan bagi penyedia dana (shahibul maal).

Jenis pembiayaan di Bank syariah sebagaimana dalam bukunya Adiwarman A. Karim yang berjudul Bank Islam, Analisis Fiqih dan Keuangan terdiri dari; Pembiayaan Modal Kerja Syariah; Pembiayaan Investasi Syariah; Pembiayaan Konsumtif Syariah; Pembiayaan Sindikasi; Pembiayaan berdasarkan Take over; Pembiayaan Letter of Credit.

Pembiayaan di Bank Syariah antara lain sebagaimana berikut:

\section{a. Konsep Dasar Modal Kerja}

Pembiayaan modal kerja mencakup tiga aspek antara lain;

1) Modal Kerja (working capital assets)

Modal kerja merupakan modal lancar (aktif) yang digunakan untuk menjalankan operasional usaha sehingga bisnis dapat berjalan dengan baik, tidak macet atau berhenti di tengahtengah jalan. Pembiayan modal kerja dapat digunakan dalam hal pembayaran persekot pembelian bahan baku, pembayaran upah buruh dll.

2) Modal Kerja brutto (gross working capital)

Modal Kerja Brutto (gross working capital) merupakan keseluruhan dari jumlah jumlah aktiva lancar (current assets). Pengertian modal kerja bruto didasarkan pada jumlah atau kuantitas dana yang tertanam pada unsur-unsur aktiva lancar. Aktiva lancar merupakan aktiva yang sekali berputar akan kembali dalam bentuk semula.

3) Modal Kerja Netto (Net working capital)

Modal Kerja Netto (Net Working capital) merupakan kelebihan aktiva lancar atas hutang lancar. Dengan konsep ini, sejumlah tertentu aktiva lancar harus digunakan untuk kepentingan pembayaran hutang lancar dan tidak tidak boleh dipergunakan untuk keperluan lain. 


\section{b. Penggolongan Modal Kerja}

Berdasarkan penggunaannya, modal kerja dapat diklasifikasikan menjadi 2 (dua) golongan yaitu:

1) Modal Kerja permanen

Modal Kerja permanen berasal dari modal kerja sendiri atau dari pembiayaan jangka panjang. Sumber pelunasan modal kerja permanen berasal dari laba bersih setelah pajak ditambah dengan penyusutan.

2) Modal Kerja Seasonal

Modal kerja seasonal bersumber dari modal jangka pendek dengan sumber pelunasan dari hasil penjualan barang dagangan, penerimaan hasil tagihan termin, atau dari penjualan hasil produksi.

\section{c. Unsur-unsur Modal Kerja Permanen}

Unsur-unsur modal kerja permanen terdiri dari:

1) Kas

Kas perusahaan harus dipelihara dalam jumlah yang cukup agar dapat memenuhi kebutuhan setiap saat diperlukan. Pemeliharaan sejumlah tertentu kas dimaksudkan untuk berbagai keperluan baik untuk transaksi sehari-hari, juga antisipasi.

Jumlah kas yang cukup memungkinkan perusahaan melakukan hal-hal sebagai berikut:

- Memanfaatkan peluang potongan harga dari pemasok jika pembayaran dilakukan sebelum jatuh tempo, atau pembayaran dilakukan di muka.

- Memanfaatkan peluang diskon dari pemasok jika pembayaran dilakukan secara tunai.

- Memberikan keleluasaan bagi manajemen perusahaan dalam memanfaatkan peluang bisnis yang datangnya tidak dapat diperkirakan.

2) Piutang dagang

Pemberian piutang dagang oleh perusahaan kepada pelanggan merupakan salah satu strategi mengantisipasi 
persaingan dengan tujuan untuk menjaga keberlangsungan hubungan dengan pelanggan. Besar kecilnya piutang dagang perusahaan ditentukan oleh hal-hal sebagai berikut:

- Kebijakan penjual yang diterapkan

- Volume penjualan kredit

- Kebijakan penagihan

- Kontinuitas penjualan

3) Persediaan (stock) bahan baku

Jumlah persediaan / stock bahan baku yang selalu tersedia di perusahaan dapat digolongkan menjadi 2 (dua) bagian, yaitu:

- Stock untuk memenuhi kebutuhan produksi normal

- Stock untuk antisipasi guna menjaga kontinuitas produkci (iron stock)

\section{d. Perputaran Modal Kerja}

Peningkatan penjualan perusahaan harus didukung oleh peningkatan produksi sehingga kelangsungan penjualan dapat terjamin. Peningkatan produksi sampai dengan batas maksimum kapasitas yang ada membutuhkan tambahan modal kerja. Tambahan modal kerja dapat dipenuhi dari sejumlah kas yang tersedia dari hasil penjualan. Selanjutnya kas dimaksud digunakan untuk membeli bahan baku sehingga produksi dapat berkesinambungan.

\section{e. Alokasi Modal Kerja}

Pengalokasian modal kerja diperuntukkan kepada unsurunsur modal kerja yaitu:

1) Alokasi kepada piutang dagang (Account Receivable Financing)

2) Pembelanjaan Persediaan barang (Inventory Financing)

\section{f. Pembiayaan Modal Kerja Syariah}

Secara umum, Pembiaayaan modal kerja syariah adalah pembiayaan jangka pendek yang diberikan kepada perusahaan untuk membiayai kebutuhan modal kerja usahanya berdasarkan prinsip-prinsip syariah. Jangka waktu pembiayaan modal kerja maksimum 1 (satu) tahun dan dapat diperpanjang sesuai dengan kebutuhan. Perpanjangan fasilitas Pembiayaan Modal Kerja (PMK) 
dilakukan atas dasar hasil analisis terhadap debitur dan fasilitas pembiayaan secara keseluruhan.

Fasilitas pembiayaan Modal Kerja dapat diberikan kepada seluruh sektor/subsektor ekonomi yang dinilai prospek, tidak bertentangan dengan syariat islam dan tidak dilarang oleh ketentunan perundang-undangan yang berlaku serta dinyatakan jenuh oleh Bank Indonesia. Pemberian fasilitas pembiayaan modal kerja kepada debitur / calon debitur dengan tujuan untuk mengeliminasi risiko dan mengoptimalkan keuntungan Bank.

Berdasarkan akad yang digunakan dalam pembiayaan syariah, jenis pembiayaan Modal kerja syariah dibagi menjadi 5 macam:

1) Pembiayaan Modal Kerja Mudharabah

2) Pembiayaan Modal Kerja Istish'na

3) Pembiayaan Modal Kerja Salam

4) Pembiayaan Modal Kerja Murabahah

5) Pembiayaan Modal Kerja Ijarah.

\section{Penelitian Terdahulu}

Penelitian Ascarya dan Yumanita (2007, h. 7-43) yang bertujuan untuk mencari solusi atas rendahnya pembiayaan bagi hasil di Perbankan Syariah di Indonesia dengan menggunakan metode Analitic Network Process (ANP) dengan mengklasifikasikan penyebab masalah ke dalam empat aspek, yaitu 1) internal bank Islam; 2) pelanggan; 3) peraturan; dan 4) pemerintah dan lembagalembaga lainnya. Penelitian ini menemukan bahwa penyebab kurangnya PLS pembiayaan bank syariah di Indonesia dapat disimpulkan menjadi dua penyebab utama dari aspek internal dan regulasi, yaitu kurangnya pemahaman dan kualitas sumber daya manusia (bankir Islam) dan kurangnya mendukung peraturan. Solusi yang disarankan adalah untuk meningkatkan pemahaman dan kualitas sumber daya manusia dengan menetapkan anggaran minimum untuk pelatihan dan pendidikan, menerapkan sistem insentif atau subsidi, menetapkan standar minimum bagi manajer bank Islam melalui berkala fit and proper test, melakukan pelatihan untuk jangka pendek kebutuhan, dan mendorong pembentukan lembaga-lembaga pendidikan ekonomi dan perbankan syariah 
untuk kebutuhan jangka panjang. solusi yang disarankan lainnya adalah untuk memberikan dukungan melalui peraturan dengan meninjau peraturan pendukung, seperti klasifikasi kolektibilitas pembiayaan PLS, dan mengembangkan sistem insentif untuk meningkatkan PLS pembiayaan. Selain itu, strategi kebijakan yang paling efektif untuk mengatasi masalah bank syariah adalah dengan menerapkan strategi yang diarahkan pasar, di mana kebijakan dimaksudkan untuk mengarahkan pengembangan bank syariah untuk tetap berjalan sesuai syariah ke arah tujuan pembangunan yang diinginkan. Yang membedakan dengan penelitian yang sedang dikaji adalah memperdalam terhadap pengelolaan bagi hasil khususnya untuk menambah pengetahuan tenaga SDM Bank Syariah.

Penelitian Idris (2015) yang bertujuan menganalisis Pengembangan Lembaga Keuangan non Bank Untuk Pemberdayaan UKM menghasilkan bahwa Lembaga perbankan masih sulit untuk memberikan akses kepada UKM di pinggiran kota dan juga di daerah pedesaan. Perumusan dan dukungan dari pemerintah, Badan Usaha Milik Negara (BUMN), perusahaan swasta, LSM dan perguruan tinggi seharusnya memberi kontribusi pada pembangunan dan penguatan UKM. Dengan kohesivenes dan keterlibatan dari stakeholders di atas, mekomendasi pengembangan model pasangan atau kekompakan yang dapat menahan kekuatan dalam memasok berbagai jenis skim dan prosedur pembiayaan serta berbagai peraturan yang digunakan untuk akses UKM.

Penelitian Asiyah, (2017) yang bertujuan untuk mengetahui Sustainability Pinjaman Bergulir UPK PNPM Perkotaan, Peluang Chaneling Bank Syariah, dengan pendekatan kualitatif dan jenis penelitian deskriptif memberikan hasil bahwa Pertama, Pinjaman bergulir UPK berkembang bagus dilihat dari Jumlah KSM maupun realisasi pinjaman bergulir, kedua, Pinjaman bergulir memiliki kinerja bagus dilihat dari LAR, PAR, ROI dan CCr. Ketiga, Pinjaman bergulir berdampak signifikan bagi perekonomian masyarakat, baik dalam bidang perdagangan, usaha kecil, pertanian, Keempat, Diharapkan agar UPK bisa bersinergi dengan Industri Keuangan terutama Industri Keuangan Syariah, Kelima, Peluang UPK bermitra dengan Industri Keuangan Syariah berkisar 52\%, yakni yang 
memiliki tingkat pengembalian pinjaman bagus, dan KSM yang telah purna status miskin. Perbedaan dengan penelitian yang sedang dikaji bahwa penelitian tersebut memberikan celah kepada peneliti untuk melihat secara mendalam kaitan pada upaya pengembangan secara mendalam terkait upaya pengembangan pembiayaan dan menambahkan variabel independen berupa inklusifitas keuangan sehingga melihat dampaknya terhadap peningkatan pembiayaan di Bank Umum Syariah di Indonesia.

Penelitian Trimulato (2016) yang bertujuan untuk mengetahui Potensi Pengembangan Produk Pembiayaan Natural Uncertainty Contract (NUC) Di Bank Syariah Terhadap Sektor Ril UMKM menghasilkan bahwa potensi pengembangan produk pembiayaan syariah masih sangat besar. Terlihat bahwa jumlah UKM terus tumbuh, maka porsi produk pembiayaan masih kecil. Hal ini menunjukkan bahwa produk pembiayaan di bank syariah sangat sesuai dengan kondisi dan karakter UKM. Potensi pengembangan produk mudharabah masih sangat besar dan sangat luas. Penelitian ini merupakan peluang dan sekaligus jawaban atas penelitian yang sedang dikaji, dengan menambahkan variabel inklusifitas diharapkan memberikan dampak strategis bagi peningkatan pembiayaan di Bank Syariah.

Penelitian Andraeny (2011) yang bertujuan untuk menguji faktor yang mempengaruhi volume pembiayaan bagi hasil dengan pendekatan kuantitatif dengan metode analisis Partial Least Square (PLS) menghasilkan bahwa Dana Pihak Ketiga, Tingkat Bagi Hasil mempengaruhi secara positif dan signifikan terhadap volume pembiayaan bagi hasil, sedangkan Non Performing Financing tidak mempengaruhi. Perbedaan dengan penelitian yang sedang dikaji bahwa upaya peningkatan pembiayaan didukung oleh pembiayaan dari masing-masing skim pembiayaan, oleh karenanya sangat berkontribusi terhadap hasil dalam penelitian yang sedang dilakukan.

\section{Metode Penelitian}

Paper ini menggunakan pendekatan kualitatif. Pendekatan kualitatif dilakukan dengan pendekatan deskriptif untuk menggambarkan dampak variabel kebijakan pengembangan 
pembiayaan dan inklusifitas keuangan terhadap peningkatan pembiayaan di Bank umum syariah Indonesia. Variabel pengembangan pembiayaan diproyeksikan kedalam objek pembiayaan Jenis penggunaan dana dan kategori usaha. Variabel inklusifitas diproyeksi ke dalam jumlah Nasabah Dana Pihak Ketiga (DPK) dan Pembiayaan, kategori tingkat kemacetan dilihat dari lapangan usaha, Sedangkan variabel Pembiayaan di proyeksi dari tingkat pembiayaan yang disalurkan.

\section{E. Pembahasan}

Regulasi Otoritas Jasa Keuangan telah memberikan kebijakan pengembangan pembiayaan dan inklusifitas keuangan bagi Perbankan di Indonesia, lebih khusus untuk Perbankan Syariah di Indonesia. Tujuan tersebut diharapkan agar fungsi intermediasi perbankan syariah sejalan dengan kebutuhan masyarakat, dan keberlanjutan Perusahaan Perbankan. Jika dilihat dari perkembangan Penggunaan dana yang dimiliki oleh Perbankan Syariah, dapat dilihat alokasi pembiayaan yang termasuk dalam alokasi Usaha Mikro Kecil dan Menengan serta Non UMKM sebagai berikut:

\section{Tabel. 3}

Jumlah pembiayaan dilihat dari Jenis penggunaan dana dan kategori Usaha Bank Umum Syariah tahun 2016

(Satuan Milyar rupiah)

\begin{tabular}{ccc}
\hline Pembiayaan & UMKM & Non UMKM \\
\hline Modal Kerja & 28,458 & 39,962 \\
\hline Investasi & 15,589 & 30,178 \\
\hline Konsumsi & - & 63,294 \\
\hline Total & 44,047 & 133,435 \\
\hline
\end{tabular}

Sumber: diolah dari Statistik Perbankan Syariah Desember 2016

Tabel. 3 menunjukkan gambaran bahwa penyaluran dana pada bank syariah di dominasi oleh nasabah Non UMKM. Besarnya relatif tinggi sebesar $75 \%$ dari total pembiayaan yang disalurkan. Dalam upaya peningkatan inklusifitas keuangan, sebagaimana pendapat Rhyne, maka hal tersebut masih secara seksama mewujudkan inklusifitas keuangan. Sesuai dengan penelitian 
Trimulato (2016) bahwa peluang pembiayaan kepada sektor UMKM dengan skim uncertainty contract masih berpeluang besar, mengingat sektor UMKM terus tumbuh. Begitu juga penelitian Asiyah (2017) bahwa Perbankan Syariah memiliki Peluang berkisar 52\% Kelompok Swadaya Masyarakat pasca bantuan dari PNPM Perkotaan yang tumbuh dan layak mendapatkan program channeling dari Lembaga Keuangan Syariah yang lebih besar. 52\% kelompok tersebut memiliki tingkat pengembalian pinjaman bagus, dan KSM tersebut telah purna status miskin. Oleh karenanya layak untuk ditindaklanjuti oleh Bank Syariah.

Kondisi UMKM yang masih rendah untuk mendapatkan pembiayaan juga ditelaah dalam penelitiannya Idris (2015) bahwa Lembaga perbankan masih sulit untuk memberikan akses kepada UKM di pinggiran kota dan juga di daerah pedesaan. Rekomendasi dari Idris adalah diperlukannya perencanaan bersama dan didukung oleh pemerintah, Badan Usaha Milik Negara (BUMN) dimana Perbankan Syariah mayoritas adalah milik BUMN meskipun sudah menjadi Perseroan Terbatas, perusahaan swasta, LSM dan perguruan tinggi seharusnya memberi kontribusi pada pembangunan dan penguatan UKM. Kontribusi perusahaan swasta barangkali lebih diarahkan untuk memberikan kesempatan kepada UMKM untuk mendapatkan alokasi pembiayaan. Kondisi masih menunjukkan bahwa sektor non UMKM lah yang mendominasi pembiayaan di Perbankan Syariah. Regulasi yang dibangun pemerintah dalam hal ini adalah Bank Indonesia melalui kebijakan moneternya belum memberikan efek positif dalam hal ini. Perbankan syariah dengan tujuannya mengejar profitabilitas, dimana perusahaan swasta yang sudah maju disitulah pembiayaan menjadi tempat. Hal tersebut perlu mendapat dukungan dari masyarakat secara keseluruhan.

Perlunya ditegakkan regulasi yang sudah dibuat, seperti pada Batas Maksimum Pemberian Kredit (BMPK) no 7/03/PBI/ 2007 tentang Batas Maksimum Pemberian Kredit Bank UMUM, Batas Maksimum Pemberian Kredit Bank Pembiayaan Rakyat Syariah (PBI no 13/5/PBI/2011) dimana satu kelompok Nasabah Pihak Tidak Terkait ditetapkan paling tinggi 30\% (tiga puluh persen) dari Modal BPRS; Batas Maksimum Pemberian Kredit Bank kepada UMKM, dalam PBI nomor 14/22/PBI/2012 yang didalamnya 
memuat jumlah pembiayaan kepada UMKM paling rendah adalah $20 \%$ dari total pembiayaan.

\section{Tabel. 4}

Jumlah Nasabah DPK dan pembiayaan BUS dan UUS Tahun 2016

\begin{tabular}{ccc}
\hline Bulan & DPK & $\begin{array}{c}\text { Pembiayaan, piutang } \\
\text { dan salam }\end{array}$ \\
\hline 1 & $14,962,301$ & $3,418,683$ \\
\hline 2 & $15,158,820$ & $3,413,676$ \\
\hline 3 & $14,911,773$ & $3,410,462$ \\
\hline 4 & $14,354,972$ & $3,452,135$ \\
\hline 5 & $14,994,386$ & $3,463,867$ \\
\hline 6 & $14,804,408$ & $3,500,726$ \\
\hline 7 & $14,975,082$ & $3,521,656$ \\
\hline 8 & $15,092,335$ & $3,548,193$ \\
\hline 9 & $16,959,699$ & $3,659,405$ \\
\hline 10 & $17,615,257$ & $3,699,262$ \\
\hline 11 & $18,063,246$ & $3,746,238$ \\
\hline 12 & $18,521,091$ & $3,801,121$ \\
\hline
\end{tabular}

Sumber: diolah dari Statistik Perbankan Syariah Desember 2016

Tabel. 4 menunjukkan bahwa pasca kebijakan inklusifitas keuangan, jumlah nasabah funding mengalami fluktuasi, dimana pada bulan kedua sempat melonjak naik, namun di bulan ketiga dan keempat mengalami penurunan serta menurun lagi pada bulan keenam. Alokasi pembiayaan relatif mengalami guncangan pada bulan kedua dan ketiga, artinya bahwa kebijakan pengembangan pembiayaan berhasil dilakukan, meskipun tidak mulus adanya. Pembiayaan memiliki ketahanan dibandingkan dengan pengelolaan dana masyarakat yang disimpan di Bank Syariah. Mengutip penelitiannya Andraeny (2011) bahwa pembiayaan bagi hasil meningkat dipengaruhi oleh Dana Pihak Ketiga dan Tingkat Bagi Hasil. Meningkatkan Dana Pihak Ketiga meningkatkan kemampuan Bank Syariah dalam mengalokasikan dananya ke dalam sektor yang memberikan profitabilitas yang cukup, dengan risiko pembiayaan yang tetap harus dipertimbangkan.

Upaya memaksimalkan pembiayaan sejalan dengan penelitian Ascarya dan Yumanita (2007, h. 7-43) disebabkan karena 
pemahaman dan Karyawan yang kualitasnya masih kurang serta regulasi peraturan yang masih dibutuhkan untuk mendukung, baik mendukung Perbankan syariah untuk benar-benar mengalokasikan dananya kepada sektor bagi hasil, sehingga berdampak pada meningkatnya pembiayaan. Hal tersebut diperlukan peningkatan pemahaman dan sumber daya manusia yang ditingkatkan kualitasnya. Hal tersebut perlu adanya kebijakan untuk alokasi anggaran pelatihan dan pendidikan yang meningkat. Guna meningkatkan semangat kerja maka diperlukan sistem insentif atau subsidi, serta diperlukan penetapan standar minimum bagi manajer bank syariah dengan dilakukan fit and proper test. Pelatihan secara jangka pendek sangat dibutuhkan, perlu didorong pembentukan lembaga pendidikan ekonomi dan perbankan syariah untuk kebutuhan jangka panjang.

Tabel. 5

Pembiayaan Macet dari masing-masing alokasi pembiayaan

\begin{tabular}{lc}
\hline \multicolumn{1}{c}{ Alokasi pembiayaan } & Rp. (Milyar) \\
\hline Rumah Tangga - Untuk Pemilikan Rumah Tinggal & 51,195 \\
\hline $\begin{array}{l}\text { Rumah Tangga - Untuk Pemilikan Peralatan Rumah } \\
\text { Tangga Lainnya }\end{array}$ & 33,183 \\
\hline Perdagangan Besar dan Eceran & 30,319 \\
\hline Industri Pengolahan & 19,745 \\
\hline Perantara Keuangan & 18,948 \\
\hline Konstruksi & 14,435 \\
\hline Real Estate, Usaha Persewaan, dan Jasa Perusahaan & 12,797 \\
\hline Transportasi, pergudangan dan komunikasi & 10,921 \\
\hline Rumah Tangga - Untuk Pemilikan Kendaraan Bermotor & 8,607 \\
\hline Pertanian, perburuan dan Kehutanan & 8,531 \\
\hline Listrik, gas dan air & 8,117 \\
\hline Pertambangan dan Penggalian & 6,604 \\
\hline Jasa Kemasyarakatan, Sosial Budaya, Hiburan dan & 4,617 \\
\hline Perorangan lainnya & 3,786 \\
\hline Jasa Pendidikan & 3,101 \\
\hline Rumah Tangga - Untuk Pemilikan Ruko atau Rukan & 3,043 \\
\hline Penyediaan akomodasi dan penyediaan makan minum & 3,030 \\
\hline Jasa Kesehatan dan Kegiatan Sosial & 3,005 \\
\hline Bukan Lapangan Usaha Lainnya & 1,512 \\
\hline Rumah Tangga - Untuk Pemilikan Flat atau Apartemen & \\
\hline
\end{tabular}




\begin{tabular}{lc}
\hline Perikanan & 1,405 \\
\hline Kegiatan yang belum jelas batasannya & 760 \\
\hline Jasa Perorangan yang Melayani Rumah Tangga & 337 \\
\hline $\begin{array}{l}\text { Admistrasi Pemerintahan, Pertahanan dan Jaminan Sosial } \\
\text { Wajib }\end{array}$ & 9 \\
\hline $\begin{array}{l}\text { Badan Internasional dan Badan Ekstra Internasional } \\
\text { Lainnya }\end{array}$ & - \\
\hline
\end{tabular}

Sumber: diolah dari Statistik Perbankan Syariah Desember 2016

Tabel. 5 menunjukkan bahwa alokasi pembiayaan yang disalurkan Bank Syariah sejatinya merata ke dalam aspek kehidupan. Namun demikian seiring tingginya pembiayaan yang disalurkan, risiko pembiayaan juga meningkat. Hal tersebut terlihat dari dominasi alokasi pembiayaan macet ada pada sektor rumah tangga kepemilikan rumah, dan kemacetan terbesar ke dua masih pada sektor rumah tangga untuk kepemilikan peralatan dan nomor ketiga dimiliki oleh sektor perdagangan besar dan eceran. Artinya kebijakan pengembangan pembiayaan harus dilakukan mitigasi resiko dengan seksama sehingga risiko pembiayaan bisa terhindar. Menurut Ascarya dan Yumanita (2017), dalam rangka meningkatkan pembiayaan, maka harus diperhatikan risiko pembiayaan macet. Hal tersebut dilakukan dengan adanya peraturan tentang klasifikasi kolektibilitas pembiayaan Profit and Loss Sharing (PLS).

\section{F. Simpulan Dan Saran}

\section{Simpulan}

Kebijakan pengembangan pembiayaan dan inklusiftas keuangan memberikan dampak signifikan bagi peningkatan pembiayaan. Namun demikian masih diiringi oleh tingkat pembiayaan macet yang tinggi. Diperlukan strategi-strategi agar kebijakan tersebut menghasilkan pembiayaan yang maksimal diantaranya dengan adanya dukungan dari pemerintah sebagai penerbit regulasi yang mendukung iklim pembiayaan, ditingkatkannya Sumber Daya Manusia Perbankan Syariah, Perbankan syariah senantiasa memberikan kebijakan pelatihan, penguatan Sumber daya manusia, memberikan insentif yang cukup serta adanya standar minimal terhadap rekrutmen manajer perbankan syariah. Perbankan syariah senantiasa 
mempertimbangkan Pengelolaan Dana Pihak Ketiga, serta tingkat bagi hasil yang digunakan dalam akad pembiayaan. Bank Syariah berpeluang melakukan kerjasama (chanelling) dengan Kelompok Swadaya Masyarakat yang telah terbebas dari kemiskinan, dan memaksimalkan pembiayaan untuk alokasi Usaha Mikro Kecil dan Menengah.

\section{Saran}

Akhir sesi paper ini memberikan saran kepada:

a. Lembaga Pendidikan Tinggi untuk terus menggunakan dan memanfaat literatur terkait paper pengembagan pembiayaan dan inklusifitas keuangan, dengan demikian akan melahirkan literatur yang bermanfaat untuk kemajuan Perbankan Syariah dan Pendidikan Ekonomi syariah.

b. Perbankan syariah di Indonesia seyogyanya memiliki kebijakan untuk memprioritas pembiayaan kepada sektor UMKM, dengan senantiasa memperhatikan tingkat resiko, sehingga dengan demikan akan meningkatkan pembiayaan di Bank Syariah.

c. Bagi Peneliti selanjutnya diperlukan penelitian lebih lanjut terkait penelitian secara kuantitatif untuk mendapatkan hasil matematis serta meluaskan capaian kebijakan yang telah diluncurkan Otoritas Jasa Keuangan dan efektifnya terhadap Perbankan Syairah di Indonesia. 


\section{DAFTAR PUSTAKA}

Andraeny, D. 2011. Analisis Pengaruh Dana Pihak Ketiga, Tingkat Bagi Hasil, Dan Non Performing Financing Terhadap Volume Pembiayaan Berbasis Bagi Hasil Pada Perbankan Syariah Di Indonesia. Simposium Nasional Akuntansi XIV, 47.

Asiyah, B. N., \& Si, M. 2014. Manajemen Pembiayaan Bank Syariah. Yogyakarta: Teras.

Wati, E. 2016. Keuangan Inklusif Bank Umum Syariah Dalam Mendukung Usaha Mikro Kecil dan Menengah. Al-Falah: Journal of Islamic Economics, 1(1), 1-18.

Idris, I. 2015. Pengembangan Lembaga Keuangan non Bank Untuk Pemberdayaan UKM. JURNAL Pengkajian KUKM, 1(2).

Karim, Adiwarman A. 2009. Bank Islam Analisis Fiqih dan Keuangan, edisi ketiga (Jakarta; PT Raja Grafindo Persada)

Rhyne, E. 2009. Microfinance for Bankers and Investors: Understanding the Opportunities and Challenges of the Market at the Bottom of the Pyramid. McGraw Hill Professional.

Trimulato, T. 2016. Potensi Pengembangan Produk Pembiayaan Natural Uncertainty Contract (NUC) Di Bank Syariah Terhadap Sektor Ril UMKM. Al-Falah: Journal of Islamic Economics, 1(1), 19-45.

Ulum, Fahrur. Inovasi Produk Perbankan Syariah di Indonesia. AlQanun: Jurnal Pemikiran dan Pembaharuan Hukum Islam, [S.1.], v. 17, n. 1, p. 33-59, july 2016

Venkatraman dan Ramanujam. V. 1986. Measurement of Business Performance in Strategy Research: a Comparison of Approaches. Academy of Management Review. Vol 11. pp.801-814 
Binti Nur Asiyah 